CHARLES UNIVERSITY IN PRAGUE, FACULTY OF PHYSICAL EDUCATION AND SPORT, DEPARTMENT OF KINANTHROPOLOGY AND HUMANITIES

\title{
TERRITORIAL JUSTICE AND SPORT: PUBLIC SUBSIDIES TO SPORT IN CZECH REGIONS
}

JAKUB POPELKA

\begin{abstract}
This study draws upon the works of Gratton and Taylor (1991) and Gratton (1984). The article discusses the concept of territorial justice and its possible use with respect to the Czech conditions. Based on statistical data provided by the Czech Statistical Office (2013) and the author's own investigations, the relationship between regional subsidies to sport from the regional authorities and selected indicators of deprivation are examined. The analysis indicates that correlations between the indicators of deprivation and sport subsidies from the regional authorities are not statistically significant. Research findings may indicate that resources were not distributed efficiently. The evidence suggests that territorial distribution of the subsidies to sport is inconsistent with the needs of the regions. In discussion, limitations of this study and future research directions are discussed.
\end{abstract}

Keywords: territorial justice, sport, Czech Republic, regional authority, subsidy, deprivation

\section{INTRODUCTION}

Understanding of sport and reasons for sport subsidization have evolved over the years. In the context of this text, sport is seen in its wider meaning as organized or casual activity of all people for the purpose of performance or well-being. In the nineteenth century the principles of the support combined, for example, improvement of life of working classes; improvement of health for war reasons; and moral welfare (Coalter, 2007). In socialists countries, sport was understood as an instrument for workers' regeneration after working hours. Nowadays, sport is perceived more comprehensively (European Commission, 2007; Coalter, 2007; Bloyce \& Smith, 2009). Most of the world operates under market economic system. However, market mechanism produces inefficiencies in allocation of resources. Gratton and Taylor (1991) distinguish two categories of market failure as the arguments for government involvement in sport: efficiency-related and equity-related. Regarding the efficiency-related arguments, market can be efficient for the participants 
but it is not necessarily efficient for society as it fails to take account of any additional social benefits of sport. "Government, accepting responsibility for social welfare, has a reason to encourage higher production and consumption - by subsidizing consumers, subsidising suppliers in the commercial and voluntary sector, or directly by supplying the product at the lower price" (Gratton \& Taylor, 1991, p. 56). Equity-related arguments may be used by government as a reason for subsidising consumers or suppliers in order to achieve equitable sport environment for all (Gratton \&Taylor, 1991).

Regardless of market failure, Veal (2002) also mentions less technical arguments for government involvement. Veal names, among others, equity/humanitarian; economic management and development; and tradition as the reasons for the involvement of government in sport and leisure. The first argument - equity/humanitarian - is based on the assumption that certain goods and services should be available to all, regardless of their ability to pay, and that some leisure goods and services are among the minimal package required for satisfactory quality of life (Veal, 2002). However, Veal points out that this idea is controversial in application with regard to taxation and lack of interest of people in sport. Moreover, subsidizing everybody for the sake of a small number of poor users is costly. Veal suggests that some means of targeting should be found. Economic management/development arguments can be observed in practice at both national or local level. The authorities often feel justified in intervening directly to assist such industries that can provide jobs or income. Concerning tradition, some publicly provided services are maintained because of tradition. Veal proceeds that there can also be lobby or interest groups which causes such situations. Nevertheless, this case may be caused naturally by popularity of a particular sport at regional level. However, if the market is supplemented or supplanted, then resource allocation is based not on demand but on criteria of equity which are politically determined (Boyne \& Powell, 1991).

The concept of territorial justice was developed by Bleddyn Davies (1968). He defined the territorial justice as an area distribution of provision of services such that each area's standard is proportional to the total needs for the services of its population. "If resources were allocated to each according to the needs of the particular area, we should get a perfect positive correlation between standards of provision and an index measuring the relative needs of each area for the service" (Gratton \& Taylor, 1991, p. 107). In this context of the territorial justice, Davies has argued that the need indicator must be based on a normative theory of intervention. For the meaning of a need indicator to be clear, the indicator must be theoretically based (Davies, 1968).

Gratton (1984) and Gratton and Taylor (1991) expanded this concept to sport and its provision. According to the authors, it is important to show that inequality in the distribution of resources results in those most in need being in receipt of these resources. The process of assessing the effectiveness of government policy involves first of looking at how the distribution of resources is related to the distribution of recreational need and secondly the extent to which the most needy receive the resources directed at them (Gratton \& Taylor, 1991). This study is focused on the first part of the process. Gratton (1984) observed tremendous variability in expenditures on sport and recreational facilities by local authorities in England and Wales. Then he proceeded to define measuring of recreational need. "The concept of recreational need is closely related to other areas of deprivation" (Gratton \& Taylor, 1991, p. 109). According to Dower et al. (1981), some 
official reports have shown that recreational disadvantage tends to coincide with social deprivation. Gratton and Taylor pointed out that recreation participation is positively related to income; occupational status; educational achievement; car owner-ship; and employment status. Gratton (1984) correlated three indicators (the number of unskilled manual workers per 1000 population in their area, the percentage of households in the area owning one car and the percentage with two cars) with subsidization of sport by local authorities. The results were surprising - every correlation coefficient had the sign if subsidies were distributed efficiently. The evidence suggested that the distribution of subsidies was consistent with resources directed to the neediest areas. In the next study (Gratton \& Taylor, 1991), more indicators of social deprivation were used. They defined Economic Z-score as it was considered to be closely related to recreational deprivation. The economic Z-score consisted of unemployment with a weight of four; percentage overcrowded households; percentage single parent households; percentage of households lacking exclusive use of basis amenities; percentage pensioners living alone; percentage of residents living in households where the head of household was born in New Commonwealth or Pakistan. The authors added "recreational index" with the percentage of households with no car and the percentage of households with the head of household having an unskilled manual occupation. These indicators have been correlated with net revenue expenditure on particular sport facilities in English and Welsh districts.

Among more contemporary studies of territorial justice related to sport, Panter, Jones and Hillsdon (2008) examined associations between household income and access to sport facilities in an English city. For all facility types except gyms, mean income was lowest amongst people who lived farthest away. In general, those living farther from facilities reported that they were less active although they did not tend to report a desire to exercise more. Deng, Walker and Strager (2008) conducted a case study of distributional equity of golf courses as they relate to Chinese residents and other disadvantaged groups in Calgary, Canada, over a 10 year time span. A practical example of the use of linkage between deprivation and sport needs can be seen on a sport-based initiative in the UK, the Spaces for Sports programme in 2004. Among the main purposes of the programme was the development of community sport facilities and increase sport participation in areas of high social and economic deprivation (Bloyce \& Smith, 2009).

Measuring deprivation is widely discussed in literature. Deprivation is often measured using indices valid for certain territories and for certain time period. During the last thirty years, there have been many different indices of socioeconomic deprivation. The indices combine different variables that can indicate potential deprivation. For example, for construction of Index of Deprivation in England in 1991, the following indicators were used: unemployment; children in low-income households; households who do not own a car; households lacking basic amenities; overcrowded households; persons aged 17 years who have not attend full-time study. The Index of Multiple Deprivation (IMD 2010) for England combines the following indices: income deprivation and employment deprivation; health deprivation and disability; education, skills and training deprivation; barriers to housing and services; crime; and living environment deprivation (Nolan et al., 2012).

Bureš (2010) from the Transparency International focused on financing of sport from the Czech regional authorities. The results of the study reveal significant differences in 
financing but also in conceptual work and subsidy procedures. Bureš also highlighted year-on-year differences which could misrepresent results of this study. It coincides with Numerato (2009) who argues that regional sport policies in the Czech Republic are less strategic, less institutionally complex, less ideologically anchored and more pragmatic and ad-hoc. Moreover, it has been argued that Czech regional public support for sport rarely serves to deliver social welfare objectives as is currently common in other countries (Numerato, 2009).

\section{PURPOSE}

The main objective of this study is to find out whether the sport subsidies from regional authorities respond to the needs of the regions in the Czech Republic according to selected indicators of deprivation.

\section{METHODS}

Based on the work of Gratton (1984) and Gratton and Taylor (1991), the author used correlation analysis to investigate the direction and strength of relationships between regional subsidies on sport and chosen indicators of deprivation. Pearson correlation coefficient was used for the purpose of the study. The indicators were selected on the basis of Gratton's study (1984), literature review and deprivation indicators used in the United Kingdom. The author also used "number of sport facilities" indicator to observe the relationship between public subsidies and number of sport facilities. Thirteen regions, which cover the whole area of the Czech Republic apart from Prague, were chosen for the study. Prague region was purposefully omitted with regard to its specific status. For the purposes of this study, the following indicators were selected for each region:

i. crimes per 1000 population (CRI);

ii. percentage of unskilled head of household (UHH);

iii. percentage of households with car $(\mathrm{PCH})$;

iv. registered unemployment rate (UNE);

v. number of sport facilities per 10000 population (QSF).

Apart from the last indicator (QSF) identified in 2006, all indicators and subsidies relate to 2011. As this is the first study of this type in the Czech Republic, the author decided not to define "sport need index" from the indicators. Thus, the indicators were separately correlated with sport subsidies per total expenditure of the authority and with the sport subsidies per head. The absolute values of all data were also ranked (1-13) to reduce the influence of extreme values.

\section{RESULTS}

Table 1 shows the amounts of sport subsidies as a percentage of total regional expenditure (Subsidy per expenditure) and per head (Subsidy per head). These "indicators" 
correspond to the results of Bureš (2010). Subsidies per expenditure vary from $0.04 \%$ to $0.49 \%$ of the overall regions' expenditures. Regarding subsidy per head, the results are also quite varied. The difference between the highest (92) and the lowest (9) amount is more than ten-fold.

Table 1. Subsidies in the regions of the Czech Republic

\begin{tabular}{|c|c|c|}
\hline Region & Subsidy per expenditure (\%) & Subsidy per head (CZK) \\
\hline STC & 0.09 & 21 \\
\hline JHC & 0.10 & 27 \\
\hline ULK & 0.49 & 81 \\
\hline LBK & 0.15 & 31 \\
\hline KHK & 0.05 & 16 \\
\hline JHM & 0.16 & 36 \\
\hline VYS & 0.12 & 46 \\
\hline KVK & 0.12 & 39 \\
\hline MSK & 0.04 & 9 \\
\hline PLK & 0.15 & 40 \\
\hline ZLK & 0.24 & 61 \\
\hline OLK & 0.32 & 92 \\
\hline PAK & 0.13 & 36 \\
\hline
\end{tabular}

The following figures (Figure 1-4) illustrate the correlations between the indicators of subsidy and selected indicators as "representatives of deprivation" ( $r$ is significant if $p$-value $<0.05$ ). The fact that the results of correlations for CRI, UHH and UNE are positive and $\mathrm{PCH}$ is negative might indicate that the subsidies are distributed with regard to the needs of regions. However, with regard to the subsidy per head, Figure 2 illustrates generally smallercorrelations than thosereported in Figure 1(subsidy perexpenditure).

All the data in Figure 3 and 4 were ranked (1-13) in order to eliminate extreme values in Figure 1 and Figure 2. Some of the significant correlations from Figures 1 and 2 seem to be insignificant in Figures 3 and Figure 4. Moreover, all the Figures indicate that there is no significant correlation between subsidies and crime, car ownership or number of sport facilities in regions. On the other hand, positive significant correlation between unemployment and subsidies persist from Figure 1 to Figure 3. 


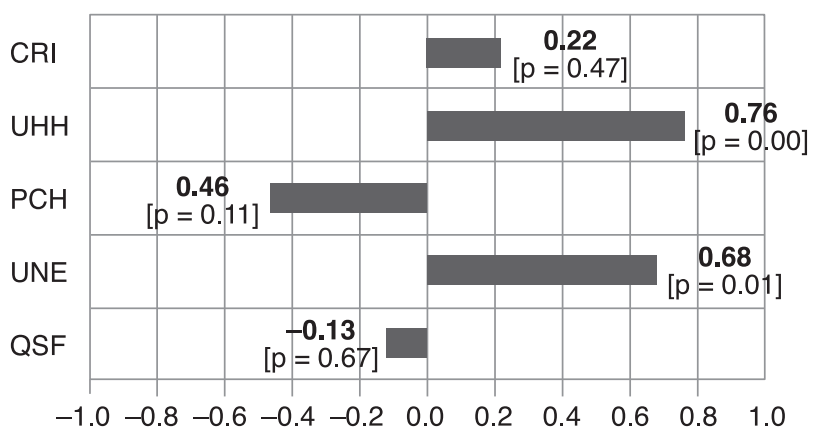

Figure 1. Relationship between deprivation and subsidies per expenditure

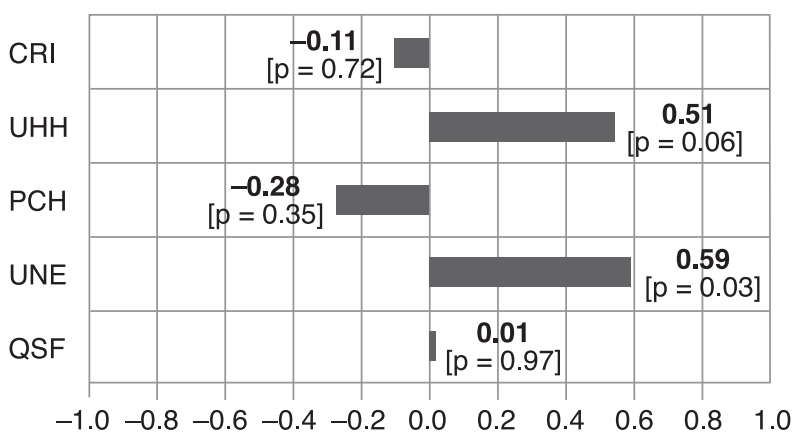

Figure 2. Relationship between deprivation and subsidies per head

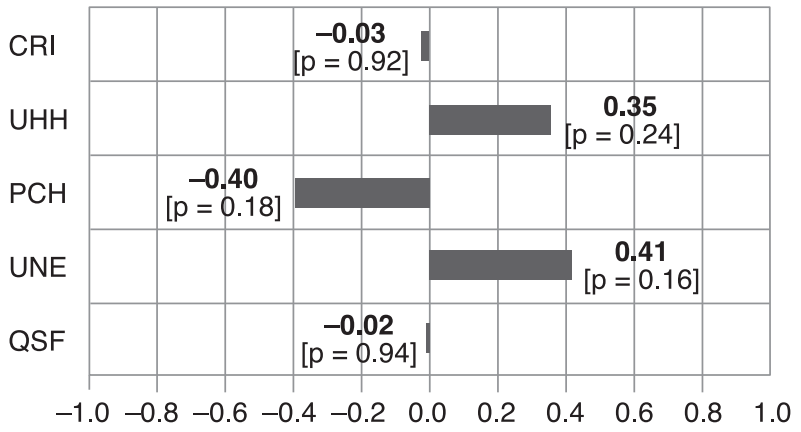

Figure 3. Relationship between ranked deprivation and ranked subsidies per expenditure 


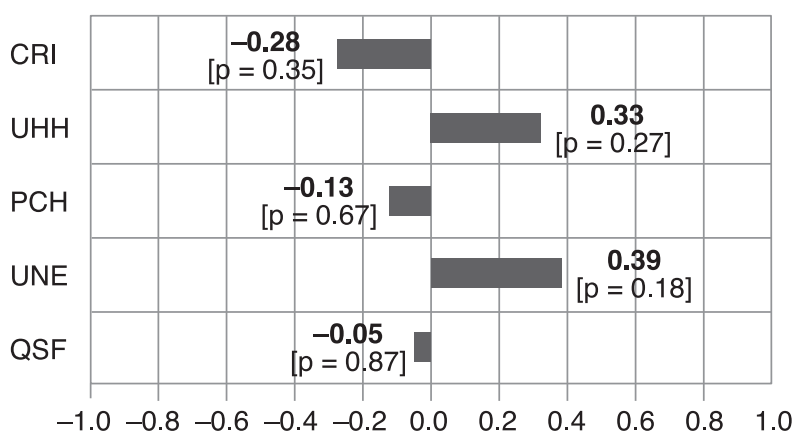

Figure 4. Relationship between ranked deprivation and ranked subsidies per head

\section{DISCUSSION}

With regard to the results, there are significant differences in sport subsidies by regional authorities in the Czech Republic. This coincides with the results of previous studies (Slepičková \& Flemr, 2007; Numerato, 2009) which stress the differences among the regions and absence of conceptual approaches by the authorities. The results show that there is not any relationship between regional subsidies and the number of sport facilities. This could indicate that certain regions with the small number of sport facilities per head are not getting closer to the regions with the higher number of sport facilities. Nevertheless, it must be stressed that the data on number of sport facilities do not respond perfectly to the current state given the year of the data and the methods of the inquiry.

Regarding the concept of territorial justice, it seems the differences among regions are not caused by the needs in regions. The significant correlations in Figures 1 and 2 may be biased by the absolute values of the indicators. According to Figure 4, it seems that subsidies do not respond to the deprivation indicators. It is worth noting that this study uses only a limited number of indicators which may not correspond to the real deprivation and the associated "sport needs". Moreover, there are further constraints which could bias the results: the size of the sample; regions defined according to administrative structure; intra-region inequity (Boyne \& Powell, 1991); haphazard expenditures for large projects; annual fluctuation of the subsidies; subsidies from municipalities and the state. Nevertheless, the study proposes a possible approach to the assessment of resources allocated to sport. With regard to the growing importance of municipalities, it appears that another study at municipal level could provide more consistent results. In addition, cooperation with experts in the field of sociology and economics could provide better understanding of deprivation and its measurement. 


\section{CONCLUSION}

Subsidies to sport from the regional authorities are at least just as important as subsidies from the state (Bureš, 2010). Nevertheless, the results suggest that the subsidies from regional authorities do not respond to the needs of the population. It could indicate that sport is still not understood in its wider meaning and potential by the regional authorities in the Czech Republic.

\section{ACKNOWLEDGEMENTS}

The study was supported by GAUK, project number 591812 - Municipal sports infrastructure and Specific University Research, number 267 602. I would like to express my gratitude to Girish Ramchandani from the Sport Industry Research Centre (Sheffield Hallam University, UK) for his support.

\section{REFERENCES}

BLOYCE, D. \& SMITH, A. (2009). Sport, policy, and development: An introduction. Milton Park, Abingdon, Oxon: Routledge.

BOYNE, G. \& POWELL, M. (1991). Territorial justice: A review of theory and evidence. Political Geography.

BUREŠ, R. (2010). Transparentnost a financování sportovní politiky na místní úrovni. In Slepičková, I. \& Slepička, P. (Eds.), Sport a politika (pp. 78-90). Praha: UK FTVS.

COALTER, F. (2007). A wider social role for sport: Who's keeping the score? London: Rutledge.

CZECH STATISTICAL OFFICE (2013). Př́jmy a životni podmínky domácností. [statistics]. Retrieved March 21., 2013, from http://www.czso.cz/csu/2012edicniplan.nsf/publ/3012-12-r_2012.

DANCS, H. \& GOLLNER, E. (2007). The role of sport in regional politics in the EU - the case of a Hungarian and an Austrian region. European journal for sport and society, 4(1), 59-68.

DAVIES, B. (1968). Social needs and resources in local services: Variations in standards of provision.

DENG, J., WALKER, G. \& STRAGER, M. (2008). Assessment of territorial justice using geographic information systems: A case study of distributional equity of golf courses in Calgary, Canada. Leisure/loisir, 32, 1, $203-230$.

DOWER, M. (1981). Leisure provision and people's needs. London: H.M.S.O.

EUROPEAN COMMISSION (2007). White paper on sport. Luxembourg, Office for Official Publications of the European Communities.

GRATTON, C. (1984). Efficiency and equity aspects of public subsidies to sport and recreation. Local Government Studies, 10, 53-74.

GRATTON, C. \& TAYLOR, P. (1991). Government and the economics of sport. Harlow: Longman.

NOLAN, M. A., TROTTER, S. \& REYNOLDS, M. (2012). Does the local economic performance league table lie? Concentric banding and the Index of Multiple Deprivation 2010. Local Economy, 27, 403-418.

NUMERATO, D. (2009). The institutionalisation of regional public sport policy in the Czech Republic. International Journal of Sport Policy and Politics, 1, 13-30.

PANTER, J., JONES, A. \& HILLSDON, M. (2008). Equity of access to physical activity facilities in an English city. Preventive Medicine, 46, 303-307.

SLEPIČKOVÁ, I. \& FLEMR, L. (2007). Sportovní politika obcí ve vztahu k aktivnímu životnímu stylu. Česká kinantropologie, 11, 3, 31-39.

SPORTS COUNCIL (1993). Council of Europe: European Sports Charter. Sports Council.

VEAL, A. J. (2002). Leisure and tourism policy and planning. Wallingford, CABI. 


\title{
ÚZEMNÍ SPRAVEDLNOST A SPORT: \\ DOTACE V OBLASTI SPORTU V KRAJÍCH ČR
}

\author{
JAKUB POPELKA
}

\section{SOUHRN}

Článek se zabývá konceptem územní spravedlnosti a jeho možným využitím v českých podmínkách. Studie čerpá z prací Grattona a Taylora (1991) a Grattona (1984). Na základě statistických údajů poskytovaných Českým statistickým úřadem (2013) a autorova vlastního šetření jsou zkoumány vztahy mezi regionálními dotacemi do sportu z krajských úřadů a vybranými ukazateli deprivace. Analýza ukazuje, že korelace mezi indikátory deprivace a dotacemi z krajských úřadů nejsou statisticky významné. Výsledky šetření mohou naznačovat, že prostředky nejsou rozděleny efektivně a územní rozdělení dotací je tak v rozporu s potřebami regionů. $\mathrm{V}$ diskusi jsou zdůrazněna omezení a možné směry dalšího výzkumu.

Klíčová slova: územní spravedlnost, sport, Česká republika, krajský úřad, dotace, deprivace

Jakub Popelka popelka.jakub@gmail.com 